Journal of Economics and Behavioral Studies

Vol. 4, No. 8, pp. 449-456, Aug 2012 (ISSN: 2220-6140)

\title{
Zakat Distribution and Growth in the Federal Territory of Malaysia
}

\author{
${ }^{*}$ Mohammed B. Yusoff1, 2 Sorfina Densumite \\ ${ }^{1}$ International Islamic University Malaysia, Malaysia \\ ${ }^{2}$ Center for Conflict Studies and Cultural Diversity Prince of Songkla University, Thailand \\ *mohammed.yusoff@iium.edu.my
}

\begin{abstract}
This research paper aims to examine the impact of zakat distribution on growth in the Federal Territory Malaysia. Specifically, an econometric study is carried out to examine the ability of zakat expenditure to affect real economic growth in the Federal Territory Malaysia by employing various econometric procedures such as the unit root tests, the cointegration tests, the vector error-correction model (VECM), and the Granger causality tests. The findings of the study suggest that zakat expenditure has a positive relationship with real GDP in the long-run. The Granger causality test indicates that zakat spending causes real economic growth with no feedback. In other words, zakat expenditure could boost GDP in the Federal Territory Malaysia both in the short-run and long-run.
\end{abstract}

Keywords: Zakat, growth, GDP, Malaysia

\section{Introduction}

Islam is a religion built upon five pillars, namely: the testimony that there is no god except Allah and Muhammad is the messenger of Allah, establishing prayer, paying zakat, fasting in the month of Ramadhan, and performing pilgrimage. Every Muslim must establish themselves on these five pillars. Therefore, it is compulsory for them to fully and correctly understand each of the pillars. Zakat is one of the five pillars of Islam. Zakat means growth or increase and by paying zakat we purify and clean our wealth and heart. All Muslims whose wealth is above the minimum zakatable limit (nisab) are required to pay zakat. The zakat payment can only be given to specific groups of people as stated in the al-Qur'an. There are eight categories of zakat recipients, namely the needy (fakir), poor (Miskin), zakat official (Amil), those whose hearts are reconciled to Islam (Muallaf), slaves and captives (al-Riqab), debtors (al-Gharimin), for the cause of Allah (Fisabilillah), and travelers (Ibnu Sabil). The rationale for imposing zakat is to prevent the concentration of wealth in a few hands, which is clearly stated in al-Qur'an in Surah al-Hashr, verse 7. Zakat also plays an important role in Islamic social welfare system to alleviate poverty in Muslim nations. In Malaysia, zakat administration is under the Islamic Council of each state, which has the authority to organize the collection and distribution of zakat on its own. Toward this end, it has developed a variety of systems such as establishing offices, employing and training officers, designing a computerised system of zakat collection, financial and reporting system, and general operation plan. The modern practices of zakat collection in Malaysia can be found at the Pusat Pungutan Zakat (Zakat Collection Centre) in the Federal Territory, which was set up in 1991 for the purpose of collecting of zakat with a more systematic management, including computerisation. It is now has become a model of zakat administration which has evolved to suit the changing environment.

The Zakat Collection Centre in the Federal Territory is an agency under the Majlis Agama Islam Wilayah Persekutuan (The Islamic Religious Council of Federal Territory) and is authorized to carry out its primary responsibility to collect zakat. This zakat collection centre covers the three Federal Territories, namely: Kuala Lumpur, Putrajaya, and Labuan. On the other hand, the distribution of zakat in the Federal Territory is done by the Baitulmal which was established in 1974. In the early stage, the Baitulmal of Kuala Lumpur focused on zakat collection, mainly on zakat fitrah (an obligatory charity imposed on every Muslim at the end of the month of Ramadhan), with a small focus on zakat in business and wealth. Currently, this institution is responsible for zakat fund management and disbursement in the Federal Territory. It distributes zakat funds to zakat recipients through the various programmes in education, health and quality of life, and economic development. Zakat is supposed to be the major source of revenues in an Islamic state. And therefore the 
main objective of this paper is to analyze the trends of zakat management, particularly on the collection and distribution. Specifically, the objective of this study is to determine the effects of zakat distribution on economic growth in the Federal Territory of Malaysia. There have been very little empirical studies to determine the effects of zakat on an economy like a study that has been done by Yusoff (2010) although there are a number of works have been done on the effects of zakat in alleviating poverty at micro level. We hope that this present study will throw more light on the importance of zakat in improving the standard of living of ummah and will spur for more empirical studies on zakat at macro level.

Types of Zakat in the Federal Territory Malaysia: The zakat collection in the Federal Territory is under the management of Zakat Collection Centre, which is an organisation under the Islamic Religious Council of Federal Territory of Malaysia.

Zakat Collection in the Federal Territory: There are several types of zakat collected in the Federal Territory, namely zakat on salaries, businesses, savings, and assets. Table 1 presents the statistics of zakat collection for each type in the Federal Territory during 2006-2008.

Table 1: Zakat Collection by Types (2006-2008)

\begin{tabular}{lllllll}
\hline Types & \multicolumn{1}{c}{$\mathbf{2 0 0 6}(\mathbf{R M})$} & $\mathbf{0}$ & \multicolumn{1}{c}{$\mathbf{2 0 0 7}(\mathbf{R M})$} & \multicolumn{1}{c}{$\mathbf{\%}$} & \multicolumn{1}{c}{$\mathbf{2 0 0 8}(\mathbf{R M})$} & $\mathbf{\%}$ \\
\hline Salaries & $89,123,574.90$ & 62.19 & $109,800,306.20$ & 64.89 & $137,571,807.25$ & 66.70 \\
Business & $22,790,507.33$ & 15.90 & $23,326,234.39$ & 13.78 & $28,702,947.32$ & 13.92 \\
Saving & $11,987,893.12$ & 8.37 & $13,670,863.27$ & 8.08 & $15,063,180.16$ & 7.30 \\
Asset & $18,758,590.82$ & 13.09 & $21,500,920.34$ & 12.70 & $23,680,791.26$ & 11.48 \\
Qadha Zakat & $279,414.86$ & 0.19 & $281,230.27$ & 0.17 & $545,092.67$ & 0.26 \\
Others & $364,422.05$ & 0.26 & $637,679.18$ & 0.38 & $697,328.62$ & 0.34 \\
TOTAL & $143,304,403.08$ & 100 & $169,217,233.65$ & 100 & $206,261,147.28$ & 100 \\
\hline
\end{tabular}

Source: Annual Report, Pusat Pungutan Zakat (PPZ), Majlis Agama Islam Wilayah Persekutuan (MAIWP).

Table 1 shows that the largest amount of zakat collection in ringgit Malaysia(RM) is the zakat on salaries which has accounted for more than $60 \%$ annually, followed by zakat on business, assets, saving, other collections, and qadha zakat. Specifically, zakat on salaries accounted for 62 percent of the total zakat collection in 2006 which increased to 65 percent and 67 percent in 2007 and 2008, respectively. In contrast, zakat collection on business slightly declined over these three years. In 2006, it accounted for 15.90 percent but decreased to 13.78 percent in 2007 and 13.92 percent in 2008. However, the total zakat collection has been increasing every year.

Channels of Zakat Payment: The Zakat Collection Centre has introduced a number of products and it also cooperates with the relevant agencies to facilitate the payment of zakat in the Federal Territory. Zakat payments can be made through the counter, internet, ATM, phone-banking, and credit card provided by a number of banks. Zakat payments also can be made directly through the Zakat Collection Centre counters which offer many modes of payment such as by cash, check, Islamic credit card, and Debit card. There are also other channels available such as through the post office counters, salary deduction, SMS-Zakat (Mobile Money) and Kiosk machines at the gas stations. In addition to the zakat payment service through kiosks at the gas stations, zakat payers can also pay zakat via kiosks placed in several Petronas service stations around the capital city. Similarly, zakat can be paid through multipurpose kiosks in the Road Transport Department and the Department of Immigration. The Zakat Collection Centre also collaborates with the Malaysia Association of Tax accountants which appoint some selected firms as zakat collection agencies. Besides, the Zakat Collection Centre also works together with the Malaysian Administrative Modernization and Management Planning Unit (MAMPU) to implement the online zakat payment through a system called My Bayar which has become a successful service to zakat collection agents. Table 2 shows the zakat collection of each channel during 2006-2008. The table shows that during 2006-2007 periods, the highest amount of zakat collection came from the salary deductions which contributed to more than 50 percent annually, followed by payment through PPZ-MAIWP counter, postal order, and bank counters. Nonetheless, in 2008, the collection through bank counters was higher than the postal order. On the other hand, in 2006 and 2007, there were no payments through money mobile, collection agents, and kiosk, however in 2008, the number of payments through these channels started to trickle in. Zakat collection through salary deduction accounted for 52 
percent in 2006 and increased to 53 percent and 56 percent in 2007 and 2008, respectively; whereas zakat collection through the PPZ-MAIWP counters contributed 44 percent, 41 percent and 39 percent in 2006, 2007 and 2008, respectively. In addition, postal order, bank counters, post office counters accounted for only a marginal amount of the total zakat collection. The zakat collection through postal order was at 2.6 percent in 2006 and declined in 2007 and 2008, while bank counters accounted for only 1 percent in 2006 and 2 percent in the following two years. The post office counters contributed only 0.2 percent over the three years. Therefore, these channels of zakat payment provided by the Zakat Collection Centre can effectively improve the total zakat collection.

Table 2: Statistics of Zakat collection through Channels (2006-2008)

\begin{tabular}{|c|c|c|c|c|c|c|}
\hline \multirow[t]{2}{*}{ Channels } & \multicolumn{6}{|c|}{ Collections (RM) } \\
\hline & 2006 (RM) & $\%$ & 2007 (RM) & $\%$ & 2008 (RM) & $\%$ \\
\hline Salary Deduction & $74,689,998.93$ & 52.12 & $91,009,773.02$ & 53.78 & $115,429,577.27$ & 55.96 \\
\hline PPZ-MAIWP Counter & $62,716,904.12$ & 43.76 & $69,818,950.23$ & 41.26 & $81,057,035.38$ & 39.30 \\
\hline Postal Order & $3,710,877.26$ & 2.59 & $4,200,747.02$ & 2.48 & $3,190,877.29$ & 1.55 \\
\hline Bank Counters & $1,832,255.91$ & 1.28 & $3,655,645.88$ & 2.16 & $5,072,702.82$ & 2.45 \\
\hline Post Office Counters & $305,264.86$ & 0.22 & $337,363.75$ & 0.20 & $506,335.38$ & 0.25 \\
\hline Credit Card & $17,993.00$ & 0.01 & $11,610.00$ & 0.01 & $12,710.00$ & 0.01 \\
\hline Cheque & $31,109.00$ & 0.02 & $183,058.75$ & 0.11 & $83,799.08$ & 0.04 \\
\hline Machine & 0.00 & 0.00 & 85.00 & 0.00 & 362.57 & 0.00 \\
\hline Money Mobile & 0.00 & 0.00 & 0.00 & 0.00 & $879,308.72$ & 0.43 \\
\hline Collection Agents & 0.00 & 0.00 & 0.00 & 0.00 & $28,438.77$ & 0.01 \\
\hline Kiosk & & & & & & \\
\hline Total & $143,304,403.08$ & 100 & $169,217,233.65$ & 100 & $206,261,147.28$ & 100 \\
\hline
\end{tabular}

Zakat Distribution: Zakat payment is compulsory for individuals who fulfil the nisab and there are also specific groups of individuals who are qualified to receive it. Therefore, it is important to fully understand the whole system of zakat, including zakat payers and zakat recipients, in order to implement zakat collection and distribution more efficiently and justly. This section shall briefly explain the eight categories of zakat recipients, namely faqir, miskin, amil, muallaf, al-riqab, al-gharimin, fisabilillah, and ibnu sabil.

Zakat Recipients: The testimony of zakat recipients is based on the principle of al-Qur'an, verses 60 of Surah at-Tauba: "Alms are for the poor and the needy, and those employed to administer the (funds); for those whose hearts have been (recently) reconciled (to Truth); for those in bondage and in debt; in the cause of Allah and for the wayfarer; a duty ordained by Allah, and Allah is full of knowledge and wisdom" (at-Tauba: 60). This verse clearly says that zakat should only be spent on eight categories of recipients, namely: Faqir, Miskin, Amil, Muallaf, Al-Riqab, Al-Gharimin, Fisabilillah, and Ibnu Sabil. We shall briefly explain each one of them.

Hardcore Poor (Faqir) A faqir is a person who has no assets or job or when his/her total income is less than 50 percent of his/her daily needs as well as the needs of the people under his/her care. Referring to the Islamic Law, the minimum standards of the needs for life are food, clothing, and shelter, also basic education and medical care.

Poor (Miskin) This is a person who has a job but his/her income only fulfils a part of his/her basic needs, and is still not sufficient to fulfil his/her daily needs and the needs of people under his/her care.

The Zakat Administrator (Amil) A person or organization directly associated with the zakat institutions to manage and administer matters related to zakat in terms of zakat collection, distribution and finance. For instance, those who qualify for zakat assistance are the collectors, distributors, custodians, clerks, accountants, informers, and officers. 
Those Whose Hearts are Reconciled to Islam (Muallaf) A person whose heart has softened or who hopes and tends to accept Islam, or a person who has embraced Islam, but the Islamic faith still remains weak. Thus, they are divided into two types, namely: one who has just embraced Islam and a non Muslim who can be persuaded to embrace Islam and not cause any danger to Muslims. Zakat is provided to Muallaf as a way to assist and enable them to start a new life in the way of Islam.

Slaves and Prisoners (Al-Riqab) These are the Muslims who are in the grips of slavery, dominated physically or mentality and have fallen into the hands of the enemies. Thus, zakat can be given for the redemption of prisoners. Most of the Islamic scholars concur that zakat may be used to release slaves whose masters are either Muslim or non-Muslim.

The Debtors (Al-Gharimin): These are people who are in debt but need to fulfil their basic needs for survival. The debt, in this case, must be for a lawful purpose or not violate the Islamic law. According to Imam Shafie, a person who is indebted for helping the society, making peace or for pure Islamic purposes are allowed to receive zakat to discharge his/her debt. But zakat is not to be distributed to a person who is indebted for unlawful purposes such as gambling, the use of intoxicants, and other immoral activities. But the debtors must do their best to settle the debt by themselves first.

For the Path of Allah (Fisabilillah) Fisabilillah refers to a person or group involves in an activity in order to encourage, defend or preach Islam. Imam Abu Hanifa and Abu Yusuf explain that fisabilillah refers to fighters who defend Islam and Muslim communities, so zakat should be given to them even if they are rich.

The Wayfarer (Ibnu Sabil) An ibnu sabil is a person who is travelling from any country and need assistance during his/her journey even if he is rich. This is the special provisions for protection the welfare of a Muslim traveller. Nevertheless, the purpose of travelling must not contradict the Islamic laws. However, before asking the zakat assistance, the travellers must find other lawful means to fulfil their needs. Therefore, zakat will be available only when the travellers are unable to fulfil their needs to return home.

Zakat Recipients in the Federal Territory: the amount of zakat distribution to each category depends on the circumstances and requirements. Table 3 shows that the distribution of zakat in the federal territory to all the categories of recipients has been increasing. The higher zakat disbursement will stimulate the economic activities within the federal territory.

Table 3: Zakat Distribution in the Federal Territory (2006-2008)

\begin{tabular}{lllllll}
\hline Recipients & \multicolumn{1}{c}{$\mathbf{2 0 0 6}(\mathbf{R M})$} & $\mathbf{9}$ & $\mathbf{2 0 0 7} \mathbf{( R M )}$ & $\mathbf{\%}$ & $\mathbf{2 0 0 8}(\mathbf{R M})$ & $\mathbf{\%}$ \\
\hline Fakir & $14,837,415$ & 14.61 & $19,363,534$ & 15.97 & $20,506,789$ & 12.24 \\
Miskin & $13,463,592$ & 13.26 & $20,675,005$ & 17.06 & $22,616,745$ & 13.50 \\
Amil & $25,685,080$ & 25.29 & $16,249,998$ & 13.40 & $31,643,535$ & 18.89 \\
Mualaf & $3,125,683$ & 3.08 & $3,796,131$ & 3.13 & $5,652,879$ & 3.38 \\
Al-Riqab & 0.00 & 0.00 & 0.00 & 0.00 & 0.00 & 0.00 \\
Al-Gharimin & $1,399,151$ & 1.38 & $1,395,073$ & 1.15 & $1,652,908$ & 0.99 \\
Ibnu Sabil & 340,704 & 0.34 & 382,981 & 0.32 & 399,643 & 0.24 \\
Fisabilillah & $42,696,782$ & 42.04 & $59,361,593$ & 48.97 & $85,035,345$ & 50.76 \\
Total & $101,548,407$ & 100 & $121,224,318$ & 100 & $167,507,847$ & 100 \\
\hline
\end{tabular}

Source: Annual Report 2006-2008, Pusat Pungutan Zakat (PPZ), Majlis Agama Islam Wilayah Persekutuan (MAIWP)

Table 3 shows that nearly half of the zakat disbursements over the three years went to fisabilillah and the other half to the remaining zakat recipients, except for al-riqab. A quarter of the zakat fund went to amil in 2006 but the amount fell almost half of 2006 in 2007 and increased a little in 2008 to 18.89 percent. The percentage of zakat distribution to fakir and miskin slightly increased from 2006 to 2007 but declined in 2008; however, in terms of volume, it has increased every year. The general criteria of the recipients of zakat in the Federal Territory of Malaysia are that the recipients must be Muslims, Malaysians, and living in the Federal Territory for at least one year. 


\section{Zakat and Economic Growth}

This section examines the relationship between zakat and economic growth. It is postulated that zakat expenditure could increase economic activities, employment, and productivity of the poor. Besides that, zakat could also be a tool to alleviate poverty. Many Muslim countries have established zakat institutions to collect and distribute zakat; however, in practice each country may have different approaches of collecting and distributing the zakat fund. There are many studies on zakat. Ahmed (2004) studies the role of zakat in poverty alleviation in twenty four idb countries. He compares the estimated funds needed to alleviate poverty and the expected zakat proceeds in order to see the scope of zakat in poverty alleviation. He finds that for countries with low per capita income and high poverty concentration, zakat collection may not be able to support all the poor in the country. Ibrahim (2006) study using panel data in selangor, Malaysia shows that zakat distribution has reduced poverty incidence while the extent of poverty and severity of poverty have decreased after the distribution of zakat. Hassan (2010) proposes a model to integrate zakat and awqaf with Islamic micro-finance for the purpose of poverty alleviation. The model incorporates zakat as a source of fund which can be distributed to fulfill basic consumption needs for the hard-core poor and provides the zakat initial fund for capital investment or business for the poor. Hassan also suggests that zakat proceed can replace government expenditure, as in the case of Bangladesh, which shows the potential ability of zakat proceed to replace foreign aid if the zakat fund is properly managed. Yusoff (2006) argues that zakat can be used as a tool of stabilization policy. He elucidates his arguments by introducing a model which incorporates zakat into a simple macroeconomic model of an Islamic economy and analyzes the role of zakat. Conceptually, the result shows that an increase in zakat expenditure will increase economic activities. Based on this result, he argues that zakat can be used as discretionary and non-discretionary fiscal policy. Yusoff (2010) extends his analysis by testing Malaysian zakat expenditure on real output using panel data. The results indicate that zakat expenditure could significantly explain the variation of output.

Yusoff (2011) investigates the impact of zakat spending and school enrollment on economic growth using panel data represented by the fourteen states of Malaysia. The results of this study support the hypothesis that zakat spending and school enrollment are important determinants of economic growth in Malaysia. The zakat spending and student enrollment could significantly explain the variation in the growth of real output represented by the growth of real GDP. Therefore, it is suggested that all Muslim countries must improve the efficiency of zakat collection and spend it prudently. A more serious effort has to be made to formulate better strategies, planning, and effective policy actions to provide the needed infrastructure and to increase the stock of human capital in accordance to the need of the nations to generate growth and sustain the development of Muslim society. Kahf (1995) investigates zakat institution in various Muslim countries. He finds that there are various patterns and models of zakat institutions in term of zakat collection and distribution with and without legal obligation. Salama (1995) conducts an empirical study of voluntary and compulsory zakat in Sudan during 1980-1990 periods. Before imposing zakat as a legal obligation, the growth of zakat proceed was sluggish. In contrast, the growth of zakat collection had dramatically increased after zakat was made compulsory. Another study by Guermat et al. (2003) shows that people in 4 GCC countries (Saudi Arabia, Kuwait, UAE, and Bahrain) favor paying zakat to charitable organisations and directly to the recipients of zakat rather than paying zakat through the government. Guermat et al. (2003) also study the collection of zakat in Sudan and found that zakat collection was small compared to the GDP during 1980-1990 periods. Similar results are obtained by Kahf (2000) when he finds that the official zakat collections in Jordan, Egypt, and Kuwait were small relative to GDP, except for Pakistan. Zakat disbursement was large in Jordan but others withheld the zakat balance for the purpose of emergency reserve. Kahf also finds that the governments of these four countries paid for the cost of administration rather than utilizing the zakat fund, and thus only a little of zakat fund was spent for administrative cost. For Sudan, Salama's study (1995) finds that there was a high portion of zakat expenditure went to the administrative expenditure.

\section{The Model}

There have been very few studies on the modelling of zakat. Yusoff (2006) develops a zakat model and uses it to conceptually elucidate the role of zakat on the economic activities. Then, Yusoff (2010) extends the model to analyze the effect of zakat distribution on the real GDP, conceptually and empirically. In this current study, we specify our model as

$G D P_{t}=\beta_{0}+\beta_{1} G Z_{t}+\beta_{2} X_{t}+\varepsilon$ 
where GDP is the real Gross Domestic Product in the Federal Territory measured in Ringgit Malaysia (RM), GZ is the nominal zakat expenditure in the Federal Territory measured in Ringgit Malaysia (RM), $\mathrm{X}$ are other independent variables which determine GDP, $\beta$ 's are the parameters to be estimated, and $\varepsilon$ is the disturbance term. We have to drop the variables $X$ in the final model to be estimated due to the difficulty in obtaining the relevant time series data with sufficient number of observations. It is hypothesised that the relationship between zakat distribution and real total output is positive. The model is estimated in log form. In this study, equation (1) is written in vector error-correction model (VECM) as suggested by Engle and Granger (1987):

$$
\begin{gathered}
{\left[\begin{array}{c}
\Delta G D P_{t} \\
\Delta G Z_{t}
\end{array}\right]=\left[\begin{array}{l}
\alpha_{0} \\
\beta_{0}
\end{array}\right]+\sum_{i=1}^{m}\left[\begin{array}{l}
\alpha_{i} \\
\beta_{i}
\end{array}\right]\left[\begin{array}{c}
\Delta G D P_{t-i} \\
\Delta G Z_{t-i}
\end{array}\right]} \\
+\left[\begin{array}{l}
\theta_{1} \\
\theta_{2}
\end{array}\right]\left[\begin{array}{l}
E C T_{1 t-1} \\
E C T_{2 t-1}
\end{array}\right]+\left[\begin{array}{l}
\mu_{1 t} \\
\mu_{2 t}
\end{array}\right]
\end{gathered}
$$

Where $\Delta$ is the first difference operator, $\alpha_{i}$, and $\beta_{i,}(i=1,2)$ are the short-run coefficients. $m$ is the lag length chosen on the basis on Akaike information criterion. ECTs are the error-correction terms which are the stationary residuals generated from the long-run co-integrating regression of Johansen multivariate process . In other words; the error-correction terms represent the adjustment of variables towards to a long-run equilibrium value. The coefficients $\theta_{1}$ and $\theta_{2}$ are expected to be negative representing the short-run adjustment coefficients towards the long-run equilibrium value, while $\mu_{i}$ are the residuals distributed with zero-mean and constant variance. A VEC model is a restricted VAR model. The VEC specification restricts the long-run behaviour of the endogenous variables to converge to their long-run equilibrium relationships and allow the short-run dynamics. In other words, the vector error correction model (VECM) identifies the shortrun dynamics of each variable in the system, and in a framework that anchors the dynamics to the long-run equilibrium relationships.

Sources of Data: This study uses the annual data from 1992 to 2007. The zakat distribution data in the Federal Territory are collected from the Annual Report of Zakat Collection Centre, Federal Territory of Malaysia and the data of Gross Domestic Product (GDP) in the Federal Territory are gathered from the Department of Statistics of Malaysia. The time series for the zakat spending of the Federal Territory prior to 1992 are not published.

Estimation Techniques: The econometric procedures used for this study include the unit root tests, the cointegration tests, the vector error-correction model (VECM), and the vector error-correction Granger causality with block exogeneity Wald tests. The unit root test is carried out on the time series data to check the stationarity of the variables in order to avoid the spurious regression. A time series is considered stationary when the mean and variance of the series are constant over time, while the value of the covariance between the two periods depends only on the gap between the periods and not on the actual time at which the covariance is considered. But, if one or more of the abovementioned conditions are not fulfilled, then the series is non-stationary. This study uses the Augmented Dickey-Fuller denoted as ADF (Dickey \& Fuller, 1979) test to examine the presence of unit roots in levels and first differences. Once the series are stationary in first differences, the next step is to apply the Johansen and Juselius (1990) techniques to test for cointegration between the variables using the VEC model. The Granger causality test considers the cause and effect between the variables. This test assumes that the information is relevant to the prediction of the variables. We will examine the short-run causality between zakat expenditure and GDP by using the VECM residuals. The lag length for this test is based on Akaike's minimum final prediction error (FPE) criterion.

\section{Results and Discussion}

This section presents the empirical results of the unit root test, cointegration test, VECM, and the Granger causality test. The first step that must be conducted before estimating the model is to inspect the time series data by testing the unit root in order to check the stationary of the variables to avoid the spurious regression results. Table 4 reports the results of Augmented Dickey-Fuller tests using lag length $\mathrm{k}=0$ for GDP and $\mathrm{k}=2$ for GZ as suggested by the Akaike Information Criterion (AIC). All the tests are conducted with intercept. The $\mathrm{ADF}$ test concludes that the series are non-stationary in level and stationary in first differences at 5 percent significant level. 
Table 4: Results of ADF Tests for Unit Root

\begin{tabular}{lll}
\hline Variable & Level & First Difference \\
\hline GDP & -0.838827 & $-3.834196^{* *}$ \\
GZ & -0.346118 & $-3.947402^{* *}$ \\
\hline
\end{tabular}

Note: ${ }^{* *}$ indicates significance at $5 \%$ level.

Table 5 provides the Johansen-Juselius cointegration test results. The number of lags is 2 as suggested by Akaike information criterion. Both the trace and maximum eigen statistics suggest that there exists a unique long-run relationship between zakat spending and GDP. The Johansen test statistic should be adjusted for the degree of freedom in the case of small sample as the Johansen procedure tends to over-rejects when the null is true. Reinsel-Ahn (1988) suggests an adjustment for the degrees of freedom by replacing $T$ in the equations of test statistic with $(T-n k)$ where $T$ is the sample size, $\mathrm{n}$ is the number of variables included in the model and $\mathrm{k}$ is the number of lags.

Table 5: Johansen's Test for the Number of Cointegrating Vectors (2 lags)

\begin{tabular}{|c|c|c|c|c|}
\hline \multicolumn{5}{|c|}{ Test Statistics } \\
\hline & \multicolumn{2}{|l|}{ Trace } & \multicolumn{2}{|c|}{ Maximal Eigen Value } \\
\hline & Null Statistic & $5 \% \mathrm{CV}$ & Statistic & $5 \% \mathrm{CV}$ \\
\hline$r=0$ & $\begin{array}{l}34.3358^{* *} \\
(25.7518)\end{array}$ & 20.2618 & $\begin{array}{c}25.3031^{* *} \\
(18.9773)\end{array}$ & 15.8921 \\
\hline$r \leq 1$ & 9.0326 & 9.1645 & 9.0326 & 9.1645 \\
\hline
\end{tabular}

Notes: ${ }^{* *}$ significant at $5 \%$ level, CV $=$ critical value. The figures in the parentheses are the adjusted test statistics.

The estimated long-run equation is

$$
\begin{aligned}
G D P_{t}= & 12.7388+0.6279 G Z_{t} \\
& (22.0078)(19.5801)
\end{aligned}
$$

where the values in the parentheses are the t-statistics. The long-run equation shows a positive relationship between zakat expenditure and the real GDP. Zakat spending could significantly explain the variations in the real GDP at least at the one percent level. Hence, a 1 percent increase in zakat expenditure would lead to an increase in the real GDP by 0.6 percent in the long-run, suggesting that zakat expenditure is an important determinant of real GDP in the Federal Territory. The VECM results with 2 lags are given as:

$$
\Delta G D P_{t}=0.1141+0.4132 E C T_{t-1}+0.1280 \Delta G Z_{t}
$$

where the values in the parentheses are the t-statistics. The diagnostic tests suggest that the VECM residuals are normally distributed as indicated by the Jarque-Bera statistic $=0.6264(0.7311)$ and the Q-statistic (lag 6) $=17.5753(0.1399)$ of Portmanteua test for autocorrelation suggests that there is no autocorrelation in the residuals where the figures in the parentheses are the probabilities. The results indicate that zakat expenditure is an important determinant of GDP in the short-run, and is significant at five percent level. The coefficient of the zakat expenditure is positive suggesting that a one percent increase in the growth of zakat expenditure will increase GDP growth by 0.12 percent in the short-run. The Granger causality test with 2 lags

\begin{tabular}{|c|c|c|c|}
\hline Variables & $\Delta$ GDP* & $\Delta \mathbf{G Z}^{\mathrm{a}}$ & $\mathbf{E C T}^{\mathbf{b}}$ \\
\hline$\Delta \mathrm{GDP}$ & - & $\begin{array}{l}17.43032 \\
(0.0002)\end{array}$ & $\begin{array}{l}0.413227 \\
(3.59807)\end{array}$ \\
\hline$\Delta \mathrm{GZ}$ & $\begin{array}{l}1.579084 \\
(0.4541)\end{array}$ & - & $\begin{array}{l}3.190196 \\
(3.42249\end{array}$ \\
\hline
\end{tabular}
is used to examine the direction of causality between GDP and zakat expenditure in the short-run. The results in Table 6 suggest that zakat expenditure causes GDP with no feedback.

Table 6: Granger Causality Tests

Notes: a Chi-square statistics, the values in parentheses are the probability.

${ }^{b}$ The values in parentheses are the $t$-statistics. 
The results suggest that zakat expenditure has a significant role in income determination; the higher the zakat expenditure the higher the economic activities represented by the real GDP.

\section{Conclusion}

The empirical results suggest that zakat spending has the ability to influence economic activities, represented by the real GDP, suggesting that zakat could be employed as an important tool to stimulate economic growth. This implies that zakat could also reduce the inequality of income distribution and wealth, decrease the gap between rich and poor, which could lead to the economic development of the ummah in the long-run. However, in practice, a lot more has to be done to improve zakat management to make zakat collection and distribution more efficient and effective.

\section{References}

Ahmed, H. (2004). Role of Zakat and Awqaf in Poverty Alleviation. Occational Paper, No. 8. Jeddah: Islamic development bank group and Islamic Research \& Training Institute.

Dickey, D. \& Fuller, W. (1979). Distribution of the Estimators for Autoregressive Time Series with a Unit Root. Journal of American Statistical Association, 74, 427-431.

Engle, R. F. \& Granger, C. W. (1987). Co-integration and Error-correction: Representation, Estimation and Testing. Econometrica, 55, 251-276.

Ibrahim, P. (2006). The Economic Role of Zakat in Reducing Income Inequality and Poverty in Selangor, PhD Thesis, Faculty of Economics \& Management, University Putra Malaysia.

Guermat, C., Al-Utaibi, A. T. \& Tucker, J. P. (2003). The Practice of Zakat: An Empirical Examination of Four Gulf Countries. Discussion Papers in Economics, the School of Business and Economics, University of Exeter.

Hassan, M. K. (2010). An Integrated Poverty Alleviation Model Combining Zakat, Awqaf, and Micro-finance. Bangladesh: Seven International Conference - The Tawhidi Epistemology Zakat and Waqaf Economy.

Johansen, S. \& Juselius, K. (1990). Maximum Likelihood Estimation and Inference on Cointegration with Application to the Demand for Money. Oxford Bulletin of Economic Statistics, 52, 169-210.

Kahf, M. (1995). Applied Institutional Models for Zakah Collection and Distribution in Islamic Countries and Communities. In El-Ashker and Sirajul Haq (Ed.). Institutional Framework of Zakah: Dimensions and Implications. Jeddah, Islamic Research and Training Institute, Islamic Development Bank.

Kahf, M. (2000). Zakah Management in Some Muslim Societies, Background Paper No. 11, Islamic Research and Training Institute (IRTI), Jeddah.

Laporan Zakat (Zakat Report). Pusat Pungutan Zakat Majlis Agama Islam Wilayah Persekutuan (Zakat Collection Centre, Federal Territory of Malaysia), Kuala Lumpur (various issues).

Reimers, H. E. (1992). Comparisons of Statistical Tests for Multivariate Cointegration. Statistical Papers, 33, 335-59.

Reinsel, G. C. \& Ahn, S. K. (1988). Asymptotic Properties of the Likelihood Ratio Test for Cointrgration in the Nonstationary Vector AR Model. Technical Report, Department of Statistics, University of Wisconsin, Madison.

Salama, A. A. (1995). Empirical Economic Effects of Obligatory and Non-obligatory Payment of Zakah to the State. In El-Ashker and Sirajul Haq (eds.), Institutional Framework of Zakah: Dimensions and Implications, Islamic Research and Training Institute, Jeddah.

Yusoff, M. B. (2006). Fiscal Policy in an Islamic Economy and the Role of Zaka. IIUM Journal of economic and management, 14(2), 117-145.

Yusoff, M. B. (2010). An Analysis of Zakat Expenditure and Real Output: Theory and Empirical Evidence. IIUM Journal of Economics and Management, 18(2), 139-160.

Yusoff, M. B. (2011). Zakat Expenditure, School Enrollment, and Economic Growth in Malaysia. International Journal of Business and Social Science, 2(6), 175-181. 